\title{
不確実性に対するリスク回避度を考慮した動的な交通システム最適配分 \\ Risk Averse Dynamic System Optimal Traffic Assignment
}

山崎 周一* ・ 赤松 隆**

By Shuichi YAMAZAKI \& Takashi AKAMATSU

\section{1. はじめに}

本研究は，交通流の制御理論の一つである動的な交 通システム最適（DSO: Dynamic System Optimal）配分 を扱う.この DSO 配分とは, 交通ネットワーク全体 で消費される総旅行時間を最小化する配分である。し かし，現実の道路の旅行時間を正確に予測することは 困難であり，DSO 配分を実現するためには，旅行時間 の不確実性を考慮することが重要である，そこで，本 研究では，旅行時間の不確実性を考虑した DSO 配分 の特性を理論的に分析する.より具体的には，その DSO 配分を確率的最適制御問題として定式化し，さら に，その配分パターンを実現するための最適制御ルー ルを求める.この最適制御ルールは，時々刻々の旅行 時間を状態変数とする Feedback 型の制御ルールであ る.ここでFeedback 型の制御とは, 状態変数の観測値 に応じて制御パターンを決定する方法である．本研究 の DSO 配分の状態変数である旅行時間は，ITS

(Intelligent Transport Systems)の発達によって観測可能 となりつつある. 従って, 旅行時閒を状態変数とする Feedback 型の制御ルールを構筑することは現実的な意 義があるだろう。

本研究のオリジナルな貢献は，旅行時間の不確実性 を考慮した DSO 配分を提案している点である. DSO 配分に関しては, 従来からいくつかの研究があるが, 本研究に類するモデルは全く検討されてきていない. Friesz ら ${ }^{1)}$ Ziliaskopoulos ${ }^{2)}$ は，一般ネットワークを対

キーワード：不確実性，交通流，交通制御

* 学生員 東北大学大学院情報科学研究科 （广980-8579 仙台市青葉区荒巻青葉 6-6 TEL 022-795-7507, FAX 022-795-7505)

**正会員 東北大学大学院情報科学研究科 （广980-8579 仙台市青葉区荒巻青葉 6-6 TEL 022-795-7507, FAX 022-795-7505)
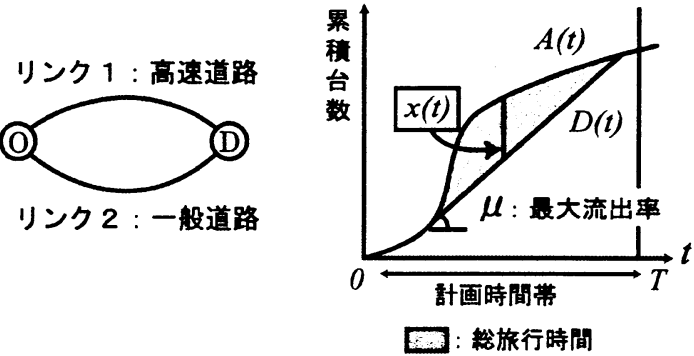

図 1 ネットワーク

象としたモデルを示しているが，最適制御ルールの理 論的な特性を明らかにしていない，また，前者は FIFO 条件を無視している点で問題があり, 後者は, “holding”という，車両を任意の時間・空間で停止さ せられるという非現実的な仮定を課している点で問題 がある. $\mathrm{Munoz}^{3)}$ ，棟方ら ${ }^{4)}$, 桑原ら ${ }^{5)}$ は単純なネッ トワークを対象とし，最適制御ルールの定性的な特性 を示している. しかし，これらのいずれの研究も，旅 行時間を確定的に扱っており，その不確実性を考慮し ていない.

本稿の構成は以下の通りである．まず，2 章で旅行 時間の不確実性を考慮した DSO 配分を確率的最適制 御問題として定式化し，3 章で最適制御ルールの定性 的な性質を示す. 4 章で定式化した問題の最適制御条 件が，いくつかの一般化相補性問題を組み合わせた問 題として表現できることを示し，5章でその問題を解 くアルゴリズムを提案する.

\section{2. 状況設定と定式化}

本章ではまず，この研究で扱う対象ネットワークを 定義する．次に，旅行時間と OD 需要の不確実性を考 慮した DSO 配分問題を定式化する.

\section{（1） 状況設定}

対象とするネットワークは，図 1 に示すようにノー ドが 2 つ, OD ペアが 1 つ, リンクを 2 本持つ。ここ 
で, リンク 1 を高速道路, リンク 2 を一般道路（一般 道路を集約したネットワークを簡略化したもの）とみ なす.

$\mathrm{OD}$ 需要は, 時間や天候など様々な要因によって変 化するため, 正確に予測することは難しい. そこで, 過去の需要の傾向から得られる OD 需要のトレンドと 確率分布を用いて, OD 需要の将来の変動を表現する. OD 需要の変動は幾何ブラウン運動に従うと仮定する と, その変化率は

$$
d q / q(t)=\alpha(t) d t+\sigma d z
$$

と表せる.ここで， $\alpha(t)$ は確定的な時間変化率， $\sigma$ は 不確実性の度合い, $d z$ は標準 Wiener 過程の増分を表 す.

\section{（2）リンク・モデルの設定}

\section{a）リンク 1 一高速道路}

自由走行時間を 0 , 最大流出率を $\mu<\infty$, 待ち行列台 数を $x(t)$ とする. 最適制御ルールを導出する過程で, 自由走行時間は二つのリンクの差で評価されため, リ ンク 1 の自由走行時間を 0 としても一般性は失われな い.

リンク 1 の流入率を $u(t)$ としたとき, 待ち行列台数 $x(t)$ の時間変化率 $d x(t) / d t \equiv \dot{x}(t)$ は以下のように与えら れる.

$$
\dot{x}(t)=\left\{\begin{array}{lll}
u(t)-\mu & \text { if } & x(t)>0 \\
\max [u(t)-\mu, 0] & \text { if } & x(t)=0
\end{array}\right.
$$

また, 任意の時刻 $t$ のリンク 1 の旅行時間は, 待ち行 列台数 $x(t)$ を通過する時間（渋滞待ち時間）なので, $x(t) / \mu$ と表せる. よって, リンク 1 の計画時間帯の総 旅行時間は図 2 に示寸累積図の累積流入台数 $A(t)$ と累 積流出台数 $D(t)$ で囲まれた領域で表せる.

\section{b）リンク 2ー一般道路}

リンク 2 の旅行時間（自由走行時間と渋滞待ち時間 の和）は $m(t)$ とする. リンク 2 は, 一般道路によって 構成されるネットワークを集約したものと見做す。よ って, リンク 2 の旅行時間 $m(t)$ の変化は制御結果に依 らず，外生的に変化する. そこで, リンク 2 の旅行時 間 $m(t)$ の变動は, 幾何ブラウン運動に従うと仮定し,

$$
d m / m(t)=\alpha(t) d t+\sigma d z
$$

とする.ここで, $\alpha(t)$ は確定的な時間変化率， $\sigma$ は不
確実性の度合い, $d z$ は標準 Wiener 過程の増分を表す。

\section{(3) 確率的最適制御問題としての定式化}

本研究ではリンク 1 の流入率 $u(t)$ を制御することに よって, ネットワーク全体で消費される “交通費用” を最小化することを考える. “交通費用” の評価指標の 一つとして，ネットワーク全体で消費される総旅行時 間（TT : Total Travel time）が挙げられるが，本研究で は, ネットワーク状態の不確実性を考慮するため, TT は確定的に求まらない. そこで, TT の期待値を最小化 する制御が考えられるが，この制御では TT の分散が 大きくなる可能性がある.つまり, 結果として多大な TT を生じさせる可能性も含んでしまう. 期待值と分散 にはトレードオフの関係があるため, 両者をバランス 良く考慮した評価指標が必要になる. 本研究では, こ のトレードオフを考慮した制御方法を開発するために, 期待効用最大化の枠組みを採用する，具体的には，ネ ットワーク全体で消費される総旅行時間 $C(t)$ の削減に よって得られる効用を最大化する. すなわち, 我々の DSO 配分問題は, 確率的最適制御問題[S-DSO]として 次のように定式化できる.

[S-DSO] $\max _{\{(t)\}} E_{0}\left[\int_{0}^{T} U(-C(\tau)) d \tau+\Phi(x(T))\right]$

ここで, 総旅行時間 $C(t)$ は,

$$
C(t)=x(t)+m(t)(q(t)-u(t)),
$$

で定義される.また， $\Phi(x(T))$ は計画時間帯終了時刻 に残っている待ち行列台数 $x(T)$ から受ける効用であ る.

ただし, 式(4)の問題は式(1), 式 (2), 式(3), 及び, 待ち行列台数 $x(t)$ と流入率 $u(t)$ の非負条件, 満期 $T$ での 待ち行列台数 :

$$
x(t) \geq 0, u(t) \geq 0, \quad x(T) \text { is free } .
$$

が制約条件となる.

\section{3. 最適制御ルール}

本研究では, 旅行時間と OD 需要の不確害性を個別 に分析する．これは，個々の要因が最適制御ルールに 与える影響を明確に区別するためである. 最適制御ル 一ルは, どちらの場合も同様の手順で導出できるため, 以下では旅行時間の不確実性を考慮した場合のみ示す。 
まず，任意の時刻 $t$ における最適值関数を定義する.

次に, 最適值関数が満たすべき条件の Hamilton-JacobiBellmn(HJB)方程式を導く.この HJB 方程式とネット ワーク状態の関係から，最適な流入率（最適制御ルー ル）が決定される.

\section{(1) HJB 方程式の導出}

最適制御条件を導出するため, 最適値関数を次のよ うに定義する.

$$
V(t, x(t), m(t)) \equiv \max _{\{u(t)\}} E_{t}\left[\int_{t}^{T} U(C(\tau)) d \tau+\Phi(x(T))\right](7)
$$

DP 原理により最適值関数を $[t, t+\Delta t]$ と $[t+\Delta t, T] に$ 分割すると以下の式が得られる.

$$
V(t, x, m)=U(w(t)) \Delta t+V(t+\Delta t, x+\Delta x, m+\Delta m)
$$

$\Delta t \rightarrow 0$ の極限をとり, 伊藤の補題 ${ }^{6}$ )を用いて展開する と,

$$
d V=\frac{\partial V}{\partial t}+\frac{\partial V}{\partial x} d x+\frac{\partial V}{\partial b} d m+\frac{1}{2} \frac{\partial^{2} V}{\partial m^{2}}(d m)^{2}
$$

となる. 整理すると, 任意の時刻 $t$ において最適値関 数が満たすべき条件の Hamilton-Jacobi- Bellmn(HJB)方 程式が導出される.

$$
0=\min _{\{u(t)\}}\left[-U(w(t))+\dot{x}(t) \frac{\partial V}{\partial x}\right]+L_{0} V
$$

ここで, $L_{0}$ は次のように定義される微分演算子である.

$$
L_{0} \equiv \alpha(t) m(t) \frac{\partial}{\partial m}+\frac{1}{2} \sigma^{2} m^{2}(t) \frac{\partial^{2}}{\partial m^{2}}+\frac{\partial}{\partial t}
$$

\section{（2）最適制御ルールの導出}

式(10)で示される HJB 方程式は, 式(2)で与えられ た待ち行列台数の時間変化率 $\dot{x}(t)$ を含むため, 待ち行 列の有無によって以下のように場合分けされる.

$$
0=\min _{\{u(t)\}} Z_{i}+L_{0} V \quad i \in 1,2
$$

$$
\begin{cases}i=1 & x(t)>0(\text { 待ち行列がある状態) } \\ i=2 & x(t)=0 \text { (待ち行列がない状態) }\end{cases}
$$

ここで， $Z_{l}$ と $Z_{2}$ は，制御変数の流入率 $u(t)$ を含む項を まとめたものである.

$$
Z_{1}=-U(-C(t))+\max [u(t)-\mu, 0] \frac{\partial V}{\partial x}
$$

$$
Z_{2}=-U(-C(t))+(u(t)-\mu) \frac{\partial V}{\partial x}
$$

$Z_{I}$ と $Z_{2}$ を最小化する $u(t)$ が最適な流入率となる.

\section{a) 待ち行列がない場合 $(x(t)=0)$}

$Z_{1}$ を最小化する流入率 $u(t)$ を求める. $Z_{1}$ は $\max$ 演算 子を含むため, $\dot{x}(t)=0$ と $\dot{x}(t)=u(t)-\mu$ に場合分けさ れる. $\dot{x}(t)=0$ の場合, つまり $u(t)<\mu$ の場合, $Z_{l}$ の一 階条件は常に負になる.

$$
\frac{\partial Z_{1}}{\partial u}=-\frac{\partial U(-C(t))}{\partial C} \frac{\partial C}{\partial u}<0
$$

よって，流入率 $u(t)$ を大きくするほど $Z_{2}$ を小さく出来 るため, 最適な流入率は

$$
\text { 制御A } u(t)=q(t) \text { if } q(t) \leq \mu
$$

と決まる. $\dot{x}(t)=u(t)-\mu$ の場合, つまり $u(t) \geq \mu$ の場 合， $Z_{l}$ を最小とする流入率は，内点解があるならば,

$$
\frac{\partial Z_{1}}{\partial u}=-\frac{\partial U(-C(t))}{\partial C} \frac{\partial C}{\partial u}+\frac{\partial V}{\partial x}=0
$$

から求められる. $\partial U(-C(t)) / \partial C$ の逆関数を $I$ と定義 すると， $Z_{1}$ を最小とする流入率は,

$$
v_{0}=q(t)-\frac{1}{m(t)} I\left(\frac{1}{m(t)} \frac{\partial V}{\partial x}\right)
$$

となる. $v_{0}$ を $m(t)$ の関数とみなしたとき, $v_{0}$ は $m(t)$ に 対して単調増加することが証明できる（証明は付録 1 に示す)．そのため，制約条件 $(\mu \leq u(t) \leq q(t))$ との 関係から,

$$
\left\{\begin{array}{ccc}
v_{0} \leq \mu & \text { if } & m(t) \leq M_{1} \\
\mu \leq v_{0} \leq q(t) & \text { if } & M_{1}<m(t) \leq M_{2} \\
q(t) \leq v_{0} & \text { if } & M_{2}<m(t)
\end{array}\right.
$$

を満たす境界 $M_{1}, M_{2}$ が存在する. したがって, 最適 な流入率は,

$$
\begin{array}{llll}
\text { 制御B : } & u(t)=\mu & \text { if } & m(t) \leq M_{1} \\
\text { 制御C }: & u(t)=v_{0} & \text { if } & M_{1}<m(t) \leq M_{2} \\
\text { 制御D : } & u(t)=q(t) & \text { if } & M_{2}<m(t)
\end{array}
$$

と決まる. 図 3 に境界 $M_{1}, M_{2}$ と最適な流入率の関係 を示す. 式(18)で与えられる最適な流入率を式(10)に代 入することで，ネットワーク状態に対応した最適制御 条件 


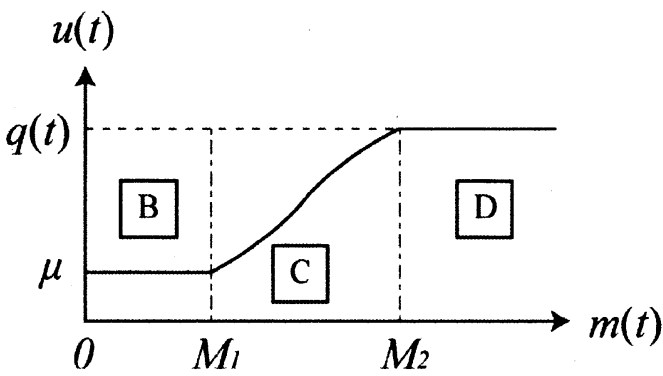

図 3 リスク回避度を考慮した場合の流入率 $(x(t)=0)$

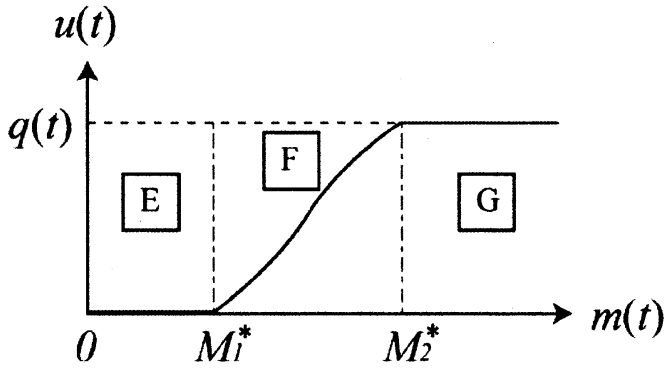

図 4 リスク回避度を考慮した場合の流入率 $(x(t)>0)$

制御A : $0=C_{1}+L_{0} V$

制御B : $0=C_{2}+L_{0} V$

制御C: $0=N_{0} V$

制御D : $0=C_{1}+L_{1} V$

が得られる.ここで,

$$
\begin{aligned}
C_{1} & =-U(0) \\
C_{2} & =-U(m(t)(\mu-q(t))) \\
L_{0} & \equiv m(t) \alpha \frac{\partial}{\partial m}+\frac{1}{2} m^{2}(t) \sigma^{2} \frac{\partial^{2}}{\partial m^{2}}+\frac{\partial}{\partial t} \\
L_{1} & \equiv(q(t)-\mu) \frac{\partial}{\partial x}+L_{0} \\
N_{0} V & \equiv-\frac{1}{m(t)} \frac{\partial V}{\partial x}+\left(v_{0}-\mu\right) \frac{\partial V}{\partial x}+L_{0} V
\end{aligned}
$$

である.

\section{b）待ち行列がある場合 $(x(t)>0)$}

$Z_{2}$ を最小化する流入率 $u(t)$ を求める， $Z_{2}$ を最小とす る流入率は, 内点解があるならば,

$$
\frac{\partial Z_{2}}{\partial u}=-\frac{\partial U(-C(t))}{\partial C} \frac{\partial C}{\partial u}+\frac{\partial V}{\partial x}=0
$$

から求められる. $\partial U(-C(t)) / \partial C$ の逆関数を $I$ と定義

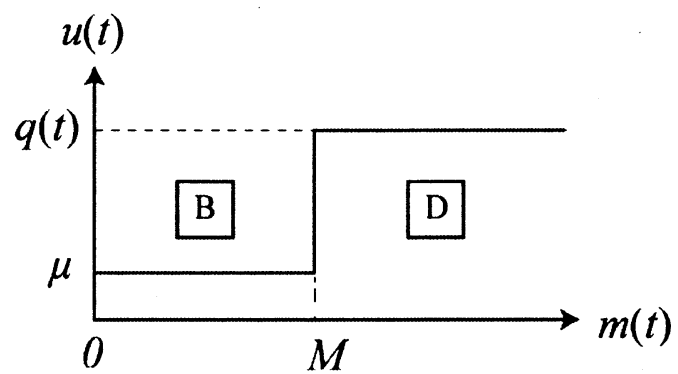

図 5 リスク中立な場合の流入率 $(\boldsymbol{x}(\boldsymbol{t})=\mathbf{0})$

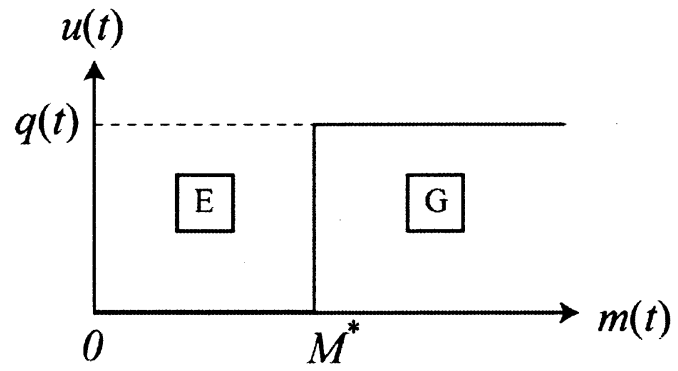

図 6 リスク中立な場合の流入率 $(x(t)>0)$

すると， $Z_{1}$ を最小とする流入率は,

$$
v_{1}=\frac{1}{d(t)}\left[m(t) q(t)-I\left(\frac{1}{d(t)} \frac{\partial V}{\partial x}\right)\right]
$$

where

$$
d(t) \equiv m(t)-x(t) / \mu
$$

となる. $v_{1}$ を $m(t)$ の関数とみなしたとき, $v_{1}$ は $m(t)$ に 対して単調増加することが証明できる. そのため, 制 約条件 $(0 \leq u(t) \leq q(t))$ との関係から，

$$
\left\{\begin{array}{ccc}
v_{1} \leq 0 & \text { if } & m(t) \leq M_{1}^{*} \\
\mu \leq v_{1} \leq q(t) & \text { if } & M_{1}^{*}<m(t) \leq M_{2}^{*} \\
q(t) \leq v_{1} & \text { if } & M_{2}^{*}<m(t)
\end{array}\right.
$$

を満たす境界 $M_{1}^{*}, M_{2}^{*}$ が存在する. したがって, 最 適な流入率は,

$$
\begin{array}{llll}
\text { 制御 } \mathrm{E}: & u(t)=0 & \text { if } & m(t) \leq M_{1}^{*} \\
\text { 制御F } \mathrm{F} & u(t)=v_{1} & \text { if } & M_{1}^{*}<m(t) \leq M_{2}^{*} \\
\text { 制御 } \mathrm{G}: & u(t)=q(t) & \text { if } & M_{2}^{*}<m(t)
\end{array}
$$

と決まる. 図 4 に境界 $M_{1}^{*}, M_{2}^{*}$ と最適な流入率の関 係を示す. 式(22)で与えられる最適な流入率を式(10) 
表 1 : ネットワークの状態別最適制御条件（旅行時間が不確実な場合）

\begin{tabular}{|c|c|c|c|c|}
\hline \multicolumn{2}{|c|}{ ネットワーク状態による分類 } & 最適制御条件 & 最適な流入率 & 制御番号 \\
\hline \multirow{4}{*}{$x(t)=0$} & $\dot{x}(t)=0$ & $0=C_{I}+L_{0} V(t, x(t), m(t))$ & $u(t)=q(t)$ & $\mathrm{A}$ \\
\hline & \multirow{3}{*}{$\dot{x}(t)=u(t)-\mu$} & $0=C_{2}+L_{0} V(t, x(t), m(t))$ & $u(t)=\mu$ & B \\
\hline & & $0=N_{0} V(t, x(t), m(t))$ & $u(t)=v_{0}$ & $\mathrm{C}$ \\
\hline & & $0=C_{1}+L_{l} V(t, x(t), m(t))$ & $u(t)=q(t)$ & $\mathrm{D}$ \\
\hline \multirow{3}{*}{$x(t)>0$} & \multirow{3}{*}{$\dot{x}(t)=u(t)-\mu$} & $0=C_{3}+L_{2} V(t, x(t), m(t))$ & $u(t)=0$ & $\mathrm{E}$ \\
\hline & & $0=N_{l} V(t, x(t), m(t))$ & $u(t)=v_{l}$ & $\mathrm{~F}$ \\
\hline & & $0=C_{f}+L_{l} V(t, x(t), m(t))$ & $u(t)=q(t)$ & G \\
\hline
\end{tabular}

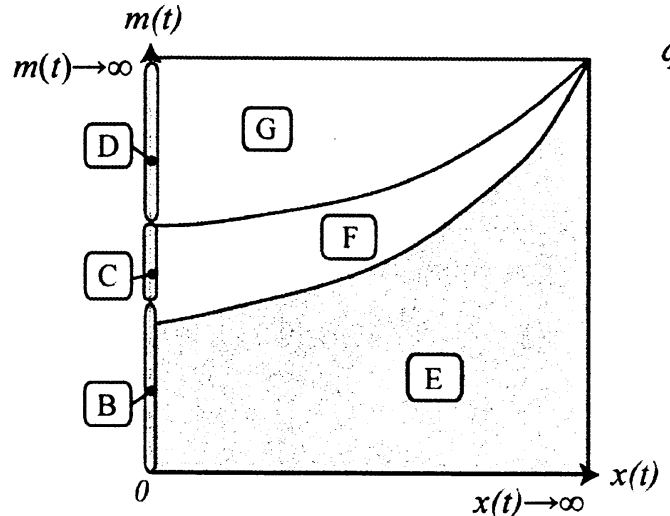

図 7 最適制御ルール（旅行時間）

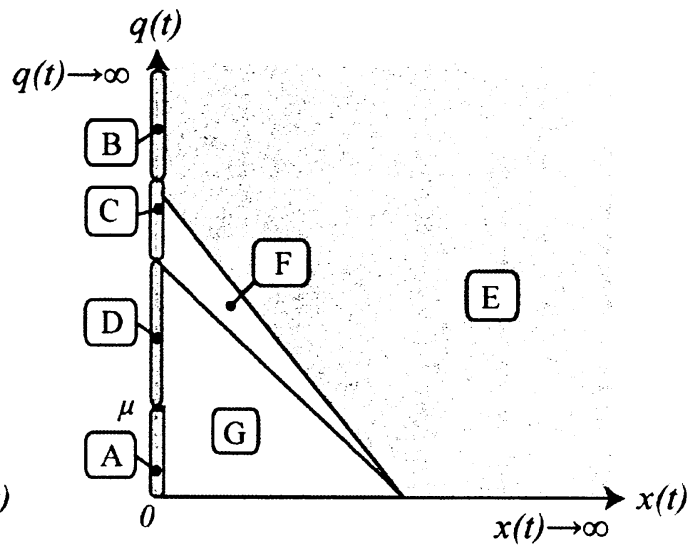

図 8 最適制御ルール（OD需要）

に代入することで，ネットワーク状態に対応した最適 制御条件

$$
\begin{array}{ll}
\text { 制御 } \mathrm{E}: & 0=C_{3}+L_{2} V \\
\text { 制御 } \mathrm{F}: & 0=N_{1} V \\
\text { 制御 } \mathrm{G}: & 0=C_{4}+L_{1} V
\end{array}
$$

が得られる.ここで，

$$
\begin{aligned}
C_{3} & =-U(-m(t) q(t)) \\
C_{4} & =-U\left(-\frac{x(t)}{\mu} q(t)\right) \\
L_{2} & \equiv-\mu \frac{\partial}{\partial x}+L_{0} \\
N_{1} V & \equiv-\frac{1}{m(t)-x(t) / \mu} \frac{\partial V}{\partial x}+\left(v_{1}-\mu\right) \frac{\partial V}{\partial x}+L_{0} V
\end{aligned}
$$

である.

以上の結果を表 1 にまとめる. なお, OD 需要が不 確実な場合の HJB 方程式も式(10)とほぼ同形であり， 同様の手順で最適な流入率と最適制御条件が得られる. 紙面の都合上，その詳細な制御ルールの提示は省略す る.

\section{最適制御ルールの定性的な性質}

\section{a）旅行時間が不確実な場合}

任意の時刻 $t$ における各制御領域は, $m(t)-x(t)$ 状態 空間で表すことができる. 図 7 は， $q(t)>\mu$ における各 制御領域を表している．例えば，待ち行列がない場合 $(x(t)>0)$, リンク 2 の旅行時間 $m(t)$ が増加すると, 制 御 $\mathrm{E} \rightarrow$ 制御 $\mathrm{F} \rightarrow$ 制御 $\mathrm{G}$ と切り替わる. これは, 一般道 路の旅行時間が一定の值を超えると, 多少の渋滞を発 生させてでも高速道路へ流入させる制御が望ましいこ とを意味する.

各制御領域はリスク回避度によって変化する. 図 7 は, リスク回避度を考慮した場合の最適制御ルールを 表している. 制御 C, 制御 F の領域は，リスク回避度 を小さくすると縮小し, 最終的にリスク中立の場合(総 旅行時間の期待値のみを考慮した場合）で消える．図 5 と図6に, リスク中立の場合の最適な流入率を示す. 図 3 と図 4 の境界 $M_{i}, M_{i}^{*}(i \in 1,2)$ の距離は, リス ク回避度が小さくなるにつれて縮まり, 最終的にリス ク中立の場合の境界 $M, M^{*}$ に一致する.つまり，制 御 C と制御 $\mathrm{F}$ の領域が消え，どちらかのリンクにすが 
ての OD 需要を配分する “bang-bang 制御”になる.

\section{b） OD 需要が不確実な場合}

図 8 は, OD 需要が不確実な場合の最適制御ルール を, 任意の時刻 $t$ における $q(t)-x(t)$ 状態空間に表してい る. 例えば, 待ち行列がある場合 $(x(t)>0)$, OD 需要 $q(t)$ の増加にともない, 制御 $\mathrm{G} \rightarrow$ 制御 $\mathrm{F} \rightarrow$ 制御 $\mathrm{E}$ に切り 替わる. a) と比較する. 旅行時間 $m(t)$ が不確実な場合, 旅行時間 $m(t)$ の増加とともに最適な流入率も増加した. 一方, OD 需要 $q(t)$ が不確実な場合, $\mathrm{OD}$ 需要の増加と ともに最適な流入率は減少する.

各制御領域はリスク回避度によって変化する. 図 8 は, リスク回避度を考慮した場合の最適制御ルールを 表している. 制御 C, 制御 $\mathrm{F}$ の領域は, リスク回避度 を小さくすると縮小し, 最終的にリスク中立の場合で 消える.つまり, リスク回避度が大きいほど, 将来、 OD 需要が増加する可能性に備えて, 高速道路の待ち 行列を抑制しておく制御になる.

\section{4. 一般化相補性問題としての表現}

前節までで，最適制御ルールの定性的な性質を明ら かにした. しかし, より詳細な定性的性質, または定 量的性質を分析するためには, 式(18), 式(22)で示す境 界 $M_{i}, M_{i}^{*}(i \in 1,2)$ を求める必要がある. $M_{1}$ は, 式(14)で示す $v_{0}$ が $\mu$ と等しくなる点であるため,

$$
\mu=q(t)-\frac{1}{m(t)} I\left(\frac{1}{m(t)} \frac{\partial V}{\partial x}\right)
$$

を満たす $m(t)$ が $M_{1}$ となることがわかる. しかし, 式 (25)に含まれる $V$ は未知数であり, $M_{1}$ を求めることが できない. 他の境界も同様に, 未知数の $V$ を含むため, 直接求めることができない，そこで, 数值的に解く必 要がある.

本章では, [S-DSO]を数值的に解くために, 最適制 御条件の持つ構造に注目し, 一般化相補性問題 (GCP : Generalized omplementarity Problem)として表現する. GCP として表現することで, 最近の数理計画論に基づ くアルゴリズムによって効率的に解ける. なお, 紙面 の都合上，旅行時間が不確実な場合のみ示すが， OD 需要が不確実な場合も同様の手順で一般化相補性問題 として表現できる.

\section{(1) $\quad m(t)-x(t)$ 状態空間}

前節で，最適制御条件 $\mathrm{E} \sim \mathrm{G}$ の各々が，ネットワー ク状態に応じて排他的に成立することを示した。 よっ て, 最適制御条件 $\mathrm{E} \sim \mathrm{G}$ は

$$
\left[C_{3}+L_{2} V\right]\left[N_{1} V\right]\left[C_{4}+L_{1} V\right]=0
$$

とまとめられる，また，表 1 に示した最適制御条件の 右辺は，非成立時には非負の值をとる，例えば，制御 $\mathrm{E}$ が成立するとき, 最適な流入率は $u(t)=0$ となり，最 適制御条件 F, G の右辺を最小と寸る流入率とは異な るため，正の值になる．制御 F，制御 G が成立すると きも同様に，他の最適制御条件の右辺を最小にする流 入率とは異なるため, 非成立時には非負の值をとるこ とがわかる.

$$
\left.\left[C_{3}+L_{2} V\right] \geq 0,\left[N_{1} V\right]\right] \geq 0,\left[C_{4}+L_{1} V\right] \geq 0
$$

式(24)と式(25)より，最適制御条件 $E \sim G$ は，一般化相 補性問題 :

[GCP2]

$$
\left\{\begin{array}{c}
{\left[C_{3}+L_{2} V\right]\left[N_{1} V\right]\left[C_{4}+L_{1} V\right]=0} \\
\left.\left[C_{3}+L_{2} V\right] \geq 0,\left[N_{1} V\right]\right] \geq 0,\left[C_{4}+L_{1} V\right] \geq 0
\end{array}\right.
$$

と表現できる.

\section{(2) 境界条件}

[GCP2]を解くためには，状態変数 $x(t), m(t)$ に関する 境界条件が必要になる．本節では，任意の時刻 $t$ にお ける境界条件, 及び満期 $T$ における終端条件を示す.

\section{i ) $\underline{x(t) \rightarrow 0}$}

表 1 より, 時刻 $t$ における待ち行列台数の時間変化 率 $\dot{x}(t)$ の関係より， 2 つの制御パターンが存在する. $\dot{x}(t)=0$ のとき,

[PDE1] $\quad 0=C_{l}+L_{0} V(t, x(t), m(t))$,

の解が [GCP2]の $x(t)=0$ での境界条件になる.

$\dot{x}(t)=u(t)-\mu$ のとき，

[GCP1]

$$
\left\{\begin{array}{c}
{\left[C_{2}+L_{0} V\right]\left[N_{0} V\right]\left[C_{1}+L_{1} V\right]=0} \\
\left.\left[C_{2}+L_{0} V\right] \geq 0,\left[N_{0} V\right]\right] \geq 0,\left[C_{1}+L_{1} V\right] \geq 0
\end{array}\right.
$$

の解が[GCP2]の $x(t)=0$ での境界条件になる.

ii ) $\underline{x(t) \rightarrow \infty}$

このとき,一般道路に全ての OD 需要を流入させる, $u(t)=0$ が最適制御となるため, 
$V(t, x \rightarrow \infty, m)=E_{t}\left[\int_{t}^{T} U(q(s) m(s)) d s+\Phi(x(T))\right](31)$ となる.

iii) $\underline{m(t) \rightarrow 0}$

一般道路の旅行時間が 0 であり, 全てのフローを一 般道路に流す制御， $u(t)=0$ が最適となる. よって,

$$
V(t, x, m \rightarrow 0)=0
$$

となる.

iv) $\underline{m(t) \rightarrow \infty}$

このとき, 全てのフローを高速道路一流す制御, $u(t)=q(t)$ が最適となるため, 最適値関数は, 時刻以降の 総待ち時間に対する不効用となる.よって,

$$
V(t, x, m \rightarrow \infty)=\int_{t}^{T} U((q(s)-\mu) s+x(s)) d s+\Phi(x(T))(33)
$$

となる.

\section{終端条件 $(t \rightarrow T)$}

最適値関数 $V(t, m, x)$ の定義より, $V(T)$ の值は, 満 期 $T$ での待ち行列がなくなるまでの間に受ける効用な ので,

$$
V(T)=\Phi(x(T))=\int_{T}^{T+s} U(x(\tau)) d \tau
$$

となる. ここで, $s$ は満期 $T$ で残っている待ち行列が なくなるまでの時間であり,$x(T+s)=0$ である.

\section{5. アルゴリズム}

前節で示した各サブ問題[GCP2], [GCP1], [PDE1] は, 連続時間・空間の問題であり, そのまま数值計算 によって解くことは難しい, そこで, 時間・空間を離 散化し, 有限次元の問題へ帰着させる.

\section{（1）状態空間の離散化表現}

連続時間を $K$ 個に分割する. 分割区間を $\Delta t$ とすると， $k$ 番目の点 $t_{k}$ は $\Delta t$ と表せる. $0 \leq k \leq K, K \Delta t=T$ であ る. 時刻 $k \Delta t$ における状態空間を離散化する. 状態変 数 $m(k \Delta t), x(k \Delta t)$ を $J+1$ 個, $I+1$ 個に分割し, $j$ 番 目の点 $m_{j}$ は $j \Delta m, i$ 番目の点 $x_{j}$ は $i \Delta x$ と表せる. また, 状態変数に対応して, 最適值関数を $V(t, m, x) \rightarrow V_{i, j}(k)$ と離散化する. 離散化された状態空間の各格子点と最 適値関数の関係を図 9 に示す. 離散化された最適值関 数を次のように表列表示する.

$$
\mathbf{V}_{i}(k)=\left\lfloor V_{i, 0}(k), \cdots, V_{i, J+1}(k)\right\rfloor
$$

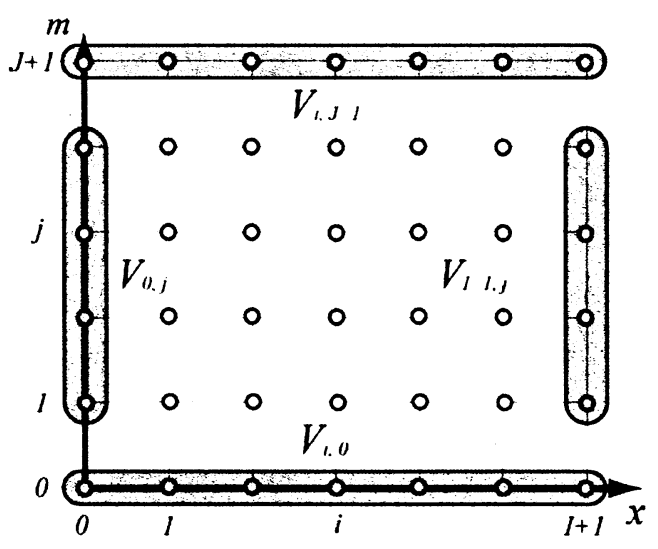

図 9 状態空間と最適値関数の離散化表現

$$
\mathbf{V}(k)=\left[V_{0,0}(k), \cdots, V_{0, J+1}(k), \cdots, V_{l+1, J+1}(k)\right]
$$

\section{（2）最適制御条件の離散化表現}

\section{a) $\boldsymbol{m}(t)-x(t)$ 状態空間}

離散時間 $k$ と $k+1$ の間に, $m(t)-x(t)$ 状態空間で満た されるべき最適制御条件 $\mathrm{E} \sim \mathrm{G}$ の右辺は

制御E :

$$
\mathbf{E} \equiv \mathbf{L}_{2}(k+1) \mathbf{V}(k+1)-\mathbf{L}_{2}(k) \mathbf{V}(k)+\mathbf{C}_{3}(k)
$$

制御 $\mathrm{F}$ :

$$
\mathbf{F} \equiv \mathbf{N}_{1}(k+1)-\mathbf{N}_{1}(k)
$$

制御 $\mathrm{G}$ :

$$
\mathbf{G} \equiv \mathbf{L}_{1}(k+1) \mathbf{V}(k+1)-\mathbf{L}_{1}(k) \mathbf{V}(k)+\mathbf{C}_{4}(k)
$$

と離散化される.ここで, $\mathbf{L}_{i}(k+1), \quad \mathbf{L}_{i}(k)(i \in 1,2)$ は 微分演算子 $L_{i}$ を適当な差分スキームで離散化して得ら れる正方行列である. また, $\mathbf{N}_{1}(k+1)$ と $\mathbf{N}_{1}(k)$ は非線 形微分方程式を離散化した $((J+1) \times(I+1)) \times 1$ の列べ クトル, $\mathbf{C}_{j}(k)(j \in 3,4)$ は $C_{j}$ を離散化した定数べクト ルである，なお，本研究では差分スキームには，数值 的に安定性の高い Crank-Nicolson 法を採用する.この 詳細は付録 2 に示す. 以上より，[GCP2]に関してまと めると，

$$
\text { [GCP2] } \min .\{\mathbf{E}(\mathbf{V}), \mathbf{F}(\mathbf{V}), \mathbf{G}(\mathbf{V})\}=\mathbf{0}
$$

と離散表現される. 


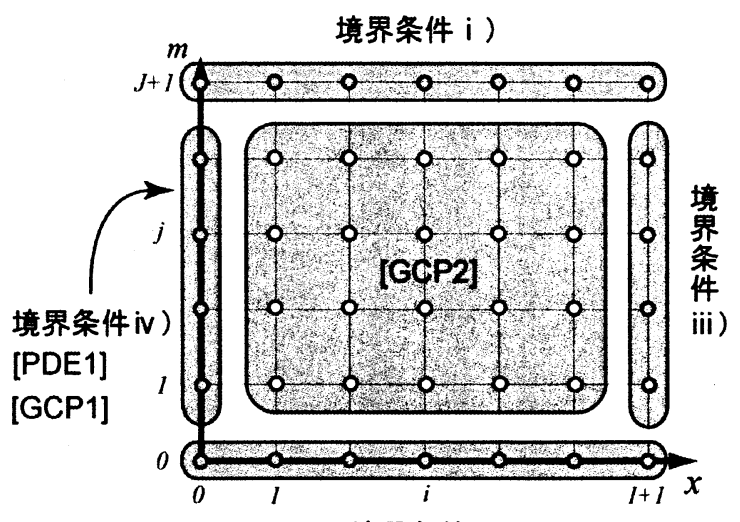

境界条件 ii )

図 10 任意の時刻 $k$ におけるサブ問題の構成

\section{b）境界条件}

離散時間 $k$ と $k+1$ の間に, $x(t)=0$ の境界上で満たさ れるべき最適制御条件 $\mathrm{A} \sim \mathrm{D}$ の右辺は

制御A :

$$
\mathbf{A} \equiv \mathbf{L}_{0}(k) \mathbf{V}_{0}(k)-\mathbf{L}_{0}(k+1) \mathbf{V}_{0}(k+1)+\mathbf{C}_{1}(k)
$$

制御B :

$$
\mathbf{B} \equiv \mathbf{L}_{0}(k+1) \mathbf{V}_{0}(k+1)-\mathbf{L}_{0}(k) \mathbf{V}_{0}(k)+\mathbf{C}_{2}(k)(39)
$$

制御C :

$$
\mathbf{C} \equiv \mathbf{N}_{0}(k+1)-\mathbf{N}_{0}(k)
$$

制御D :

$$
\mathbf{D} \equiv \mathbf{L}_{1}(k+1)-\mathbf{L}_{1}(k)+\mathbf{C}_{1}(k)
$$

と離散化される.ここで, $\mathbf{L}_{i}(k+1), \mathbf{L}_{i}(k)(i \in 0,1)$ は 微分演算子 $L_{i}$ を適当な差分スキームで離散化して得ら れる正方行列, $\mathbf{N}_{0}(k+1)$ と $\mathbf{N}_{0}(k)$ は非線形微分方程式 を離散化した $(J+1) \times 1$ の列ベクトル, $\mathbf{C}_{j}(k)(j \in 1,2)$ は $C_{j}$ を離散化した定数ベクトルである，以上より，連続 時間・空間の[PDE1], [GCP1]に対応する問題は,

[PDE1]

$$
\mathbf{A}\left(\mathbf{V}_{0}\right)=0
$$

[GCP1] $\min .\left\{\mathbf{B}\left(\mathbf{V}_{0}\right), \mathbf{C}\left(\mathbf{V}_{0}\right), \mathbf{D}\left(\mathbf{V}_{0}\right)\right\}=\mathbf{0}$

と離散表現される.

\section{（3）全体のアルゴリズム}

以上の式(35) (39)で定式化された問題を解くアル ゴリズムを示す. 式(38), 式(40), 式(41)で示される最 適制御条件は，仮に $\mathbf{V}(k+1)$ を既知とすれば， $\mathbf{V}(k)$ の みを未知変数とする問題となる. 式(34)の終端条件よ

\section{[Alg-S-DSO]}

(最適值関数の終端条件)

$$
\begin{gathered}
\mathbf{V}(K):=\boldsymbol{\Phi}(\mathbf{x}(K)) \\
(\text { 時間ループ) }
\end{gathered}
$$

\section{for $k:=K-1$ to 0 step 1 do}

境界条件 i)・ii)を用いて， $x(t)=0$ のときの最適值関数 $\mathbf{V}^{K}$ を求める. if $q(k) \leq \mu$ then

$$
\begin{aligned}
& \text { end } \\
& \text { V }
\end{aligned}
$$$$
\text { else if } \mu<q(k) \text { then }
$$

$$
\mathbf{V}_{0}(k):=[\text { Alg-GCE1] }
$$

end

上で求めた $\mathbf{V}_{0}(k)$ を境界条件として用いて, $x>0$ のときの最適値関数 $\mathbf{V}(k)$ を求める:

$$
\mathbf{V}(k):=[\mathrm{Alg}-\mathrm{GCP} 2]
$$

end

図 11 [S-DSO]を解くアルゴリズム

り，満期 $T$ の最適值関数 $\mathbf{V}(T)$ は与件である. したが って, 時点 $k=0$ から $k=K$ で定義された一群の問題は, 時点 $k=K$ から $k=0$ 一と後ろ向きに考えれば, 各時点 $k$ ごとに逐次的に解くことができる.

任意の時刻 $k$ におけるサブ問題の解法を示す. $m(t)$ $-x(t)$ 状態空間でのサブ問題は図 10 のように構成され る. 境界条件 i) ｉii)は独立に計算できる. 境界条件iv） は，境界条件 i)，ii)の下で[PDE1]，もしくは[GCP1]を 解く. 最後に, 境界条件 i) iv)の下で[GCP2]を解く. 各サブ問題を解くアルゴリズムを[Alg-PDE1], [Alg-GCP1], [Alg-GCP2]とすると, 本問題を解くアル ゴリズムは図 11 のようにまとめられる.

\section{（4）各時刻の問題を解くアルゴリズム}

本節では，サブ問題を解くアルゴリズムを示す.

[PDE1]は連立方程式を解く問題に帰着する. そのた め, [Alg-PDE1]は Jacobi 法, SOR 法など, 既存のアル ゴリズムを用いることができる.

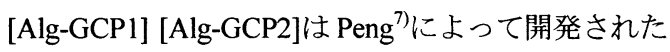
アルゴリズムを採用する．このアルゴリズムを用いて [GCP2]を解く場合, まず[GCP2]と等価な非線形万程式 


$$
\mathbf{H}(\mathbf{V}) \equiv \min .\{\mathbf{E}(\mathbf{V}), \mathbf{F}(\mathbf{V}), \mathbf{G}(\mathbf{V})\}=\mathbf{0}
$$

を，以下の滑らかな関数 ;

$$
\begin{aligned}
& \mathbf{H}(\mathbf{V}(k), \xi) \\
& \equiv-\xi \ln \left\{\exp \left(-\frac{\mathbf{E}}{\xi}\right)+\exp \left(-\frac{\mathbf{F}}{\xi}\right)+\exp \left(-\frac{\mathbf{G}}{\xi}\right)\right\}
\end{aligned}
$$

で近似する. $\mathbf{H}(\mathbf{V}(k), \xi)$ は微分可能であり， $\xi \rightarrow 0$ と したときに[GCP2]の解と一致とする. そこで，ニュー トン法によって $\mathbf{H}(\mathbf{V}(k), \xi)=\mathbf{0}$ を満たす解へ近づけな がら， $\xi$ をさくし, [GCP2]の解を求める. アルゴリ ズムの詳細は付録 3 に示す.

\section{6. おわりに}

本研究では, 旅行時間と OD 需要が不確実な場合の DSO 配分を定式化し, 最適制御ルールの定性的な性質 を明らかにした。 そして，最適制御ルールの定量的な 特性を分析するために, 最適制御問題を解くアルゴリ ズムを開発した。

\section{参考文献}

1) T.L.Friesz, J.Luque, R.L.Tobin, and B.W.Wie. : Dynamic Network Traffic Assignment Considered as a Continuous Time Optimal Control Problem, Operation Research, Vol.37, pp.893-901, 1989.

2) A.K.Ziliaskopoulos. : A Linear Programming Model for the Single Destination System Optimum Dynamic Traffic Assignment Problem, Transportation Science, Vol.34, pp.1-12, 2000.

3) J.C.Munoz, J.A.Laval. : System Optimal Dynamic Traffic Assignment Graphical Solution Method for a Congested Freeway and One Destination, Transportation Research Part B, Vol.40, pp.1-15, 2006.

4) 棟方章晴・赤松隆 : 旅行時間の不確実性を考慮した動的 システム最適配分問題の解法, 土木計画学研究·講演集 30 , 2004.

5)桑原雅夫, 吉井稔雄, 熊谷香太郎 : 動的システム最適配分 とランプ流入制御に関する研究 -簡略ネットワークにお ける基礎的分析-, 土木学会論文集, No.667/IV, pp.59-71, 2001.
6) ベァーント・エクセンダール 谷ロ説男訳 : 確率微分方程 式, Springer, 1999.

7) J.M.Peng, Z.Lin. : A Non-interior Continuation Method for Generalized Linear Complementarity Problems, Mathematical Programming, Vol. 86, pp. 533-563, 1999.

\section{付録 1: $v_{i}(i \in 0,1)$ の単調性の証明}

ここでは，式(14)で示す $v_{0}$ が $m(t)$ に対して単調増加 な関数であることを証明する. そこで, $v_{0} を m(t)$ につ いて微分すると,

$$
\frac{\partial v_{0}}{\partial m}=\frac{1}{m^{2}(t)} I(A(t))+\frac{1}{m^{3}(t)} \frac{\partial V}{\partial x} \frac{\partial I}{\partial A},
$$

where

$$
A(t)=\frac{1}{m(t)} \frac{\partial V}{\partial x}
$$

となる. $I(A(t))$ は効用関数の一階微分 $\partial U / \partial C$ の逆関 数である.したがって, $\partial I / \partial A>0$ となる.また， $\partial V / \partial x$ は, 待ち行列台数 $x(t)$ の微小変化に対する最適 值関数 $V$ の増分であり, $\partial V / \partial x>0$ である. よって, $\partial v_{0} / \partial m>0$ となり,$v_{0}$ を $m(t)$ について単調増加であ ることが言える． $v_{1}$ についても同様に証明することが できるが，紙面の都合上，省略する.

\section{付録 2: Crank-Nicolson 法}

差分スキームには陽的差分法, 陰的差分法, Crank -Nicolson 法などがある. 本研究では，陽的差分法や陰 的差分法より数値計算上の安定性に優れている Crank-Nicolson 法を用いる. 具体例として, 最適制御 条件 A を Crank-

Nicolson 法を用いて差分化する．最適制御条件 A は,

$$
0=C_{1}+L_{0} V
$$

であり，その偏微分演算子 $L_{0}$ を Crank-Nicolson 法を用 いて差分化すると，

$$
m(t)=j \Delta m
$$

$$
\frac{\partial V}{\partial m}=\frac{V_{i, j+1}(k)-V_{i, j-1}(k)}{4 \Delta m}+\frac{V_{i, j+1}(k-1)-V_{i, j-1}(k-1)}{4 \Delta m}
$$




$$
\begin{gathered}
\frac{\partial^{2} V}{\partial m^{2}}=\frac{V_{i, j+1}(k)-2 V_{i, j}(k)+V_{i, j-1}(k)}{2(\Delta m)^{2}} \\
+\frac{V_{i, j+1}(k-1)-2 V_{i, j}(k-1)+V_{i, j-1}(k-1)}{2(\Delta m)^{2}} \\
\frac{\partial V}{\partial t}=\frac{V_{i, j}(k-1)-V_{i, j}(k)}{\Delta t}
\end{gathered}
$$

となる. 差分化された式を未知数と既知数に整理する ことで, 式(38)で表される $(J+1) \times 1$ 個の連立方程式が 得られる.

\section{付録 3:- 一般化相補性問題を解く Peng のアルゴリズム}

\section{STEP 0 初期值の設定}

$\mathbf{V}(k):=\mathbf{0}, \quad \varepsilon_{0}>0, \omega \in(0,1), \delta_{1} \in(0,1), \quad \delta_{2} \in(0,1)$

$, \xi^{(0)}>0, \gamma \geq \frac{\mathbf{H}\left(\mathbf{V}^{(0)}, \xi^{(0)}\right)}{\min \left(\xi^{(0)}, 1\right)}, \quad n=0$.

STEP $1 \mathbf{V}^{(n)}$ のときの Newton Step の決定

もし, $\nabla_{\mathbf{v}} \mathbf{H}\left(\mathbf{V}^{(n)}, \xi^{(n)}\right)$ が正則の場合，停止する

もし, $\left\|\mathbf{H}\left(\mathbf{V}^{(n)}\right)\right\| \leq \varepsilon_{0}$ の場合, $\mathbf{V}^{(n)}$ を近似解とする.

それ以外の場合, 以下の連立方程式 :

$$
\nabla_{\mathbf{v}} \mathbf{H}\left(\mathbf{V}^{(n)}, \boldsymbol{\xi}^{(n)}\right) \mathbf{d}^{(n)}+\mathbf{H}\left(\mathbf{V}^{(n)}, \boldsymbol{\xi}^{(n)}\right)=0
$$

を解き, Newton stepd $\mathbf{d}^{(n)}$ を求める.

STEP $2 \mathbf{V}^{(n+1)}$ の決定

$$
h^{(n)}:=\max \left\{1, \alpha_{1}, \alpha_{1}^{2}, \cdots\right\}
$$

ただし， $h^{(n)}$ は次式を満たす。

$$
\left\|\mathbf{H}\left(\mathbf{V}^{(n)}+h^{(n)} \mathbf{d}^{(n)}, \xi^{(n)}\right)\right\| \leq\left(1-\omega h^{(n)}\right) \min \left\{\xi^{(n)}, 1\right\}
$$

求めた $h^{(n)}$ を用いて， $\mathbf{V}^{(n+1)}$ を算出する.

$$
\mathbf{V}^{(n+1)}:=\mathbf{V}^{(n)}+h^{(n)} \mathbf{d}^{(n)}
$$

STEP $3 \xi^{(n)}$ の決定

$$
\left(\mathbf{V}^{(n+1)}, \min \left\{\alpha_{3}, \xi^{(n)}\right\} \xi^{(n)}\right) \in N\left(\gamma, \min \left\{\alpha_{3}, \xi^{(n)}\right\} \xi^{(n)}\right)
$$$$
\text { ならば, } v^{(n)}:=1-\min \left\{\alpha_{3}, \xi^{(n)}\right\} \text { とする. }
$$

それ以外の場合, $v^{(n)}:=\max \left\{\alpha_{2}, \alpha_{2}^{2}, \cdots\right\}$ とする. た だし， $v^{(n)}$ は次式を満たす。

$$
\left(v^{(n+1)},\left(1-v^{(n)}\right) \xi^{(n)}\right) \in N\left(\gamma,\left(1-v^{(n)}\right) \xi^{(n)}\right.
$$

求めた $v_{k}$ を用いて, $\xi^{(n+1)}$ を算出する.

$$
\xi^{(n+1)}:=\left(1-v^{(n)}\right) \xi^{(n)}
$$

STEP4 : $n:=n+1$ として, STEP1 へ戻る.

\section{不確実性に対するリスク回避度を考慮した動的な交通システム最適配分}

山崎周一・赤松隆

本稿の目的は, 旅行時間の不確実性を考慮した動的システム最適配分を定式化し, 最適制御ルールを求めることである. その上で, 最適制御ルールの定性的な特性, リスク回避度が最適制御ルールに与える影響を分析する. その結果, リスク 回避度を考慮した場合は，リスク中立な場合と比較して 1) 高速道路への流入に消極的になること，2）リスク中立の場合 では存在しない制御方法が採用されること，がわかった．また，最適制御ル一ルを定量的に分析するため，定式化した問 題を解くアルゴリズムを提示する.

\section{Risk Averse Dynamic System Optimal Traffic Assignment}

By Shuichi YAMAZAKI \& Takashi AKAMATSU This paper presents a method for solving a dynamic system optimal (DSO) traffic assignment problem with uncertain travel time. Formulating the DSO assignment in a network with two parallel links as a stochastic control problem, we derive the optimality conditions of the assignment problem. We then show that the optimality conditions can be equivalently stated as a dynamical system of generalized complementarity problems (GCP). Based on this reformulation, we provide an efficient algorithm for solving the stochastic control problem. 